\title{
«ПОКЛИКАННЯ ДО ПОЛІТИКИ» М. ВЕБЕРА ТА УПРАВЛІНСЬКА КУЛЬТУРА СУЧАСНОГО УКРАЇНСЬКОГО ПОЛІТИКУМУ
}

\section{"CALL TO POLITICS" BY M. WEBER AND MANAGEMENT CULTURE OF MODERN UKRAINIAN POLITICS}

\begin{abstract}
Стаття присвячена одному з фрундаментальних напрацювань Макса Вебера, що найбільше відповідає управлінській науці як окремій галузі наукових знань. Ідеться про дослідження у сорері політики, влади й управління, яке досить чітко й аргументовано викладає М. Вебер у праці «Покликання до політики». У ній учений робить детальний аналіз ролі та значення політики як профресії; хто може бути покликаний до політики яким має бути політик, управлінець; які норми і принципи ведення політики; якими якостями управлінської культури повинні володіти політики, управлінці, а також - чи взагалі чі якості можливі в політичній та управлінській діяльності.

Нині політика дуже тісно пов'язана з таким інститутом держави, як влада й управління. Вона є профессіє управлінської діяльності, оскільки керівниитво державними і суспільними справами беруть на себе переважно політичні партії, об'єднання й окремі політики-лідери. Добре че чи погано - розсудить історія, але зараз че реальність, об'єктив ний фракт. Тому стають актуальними розробки класиків щодо політики як профресії, якою мають займатися покликані до цієі справи, профессійно підготовлені люди.

Сучасний український політикум, на жаль, не зовсім відповідає критеріям, про які пише $M$. Вебер. Звідси постає проблема донесення до них науково-практичних розробок, ідей та теорій класиків управлінської думки, яким, безумовно, є М. Вебер. У даній публікації автор намагатиметься в доступній формі викласти думки вченого про політику і політика-управліния, а також про те, якими ознаками та якостями управлінської культури має володіти український політикум, який репрезентує собою державне управління.

Ця стаття $\epsilon$ продовженням публікації автора, яка вийшла у 16 випуску за 2020 рік журналу «Публічне управління $і$ адміністру вання в Україні», а саме «Три чисті типи легітимного панування»: управлінська культура М. Вебера і сучасність».

Ключові слова: управлінська культура, політика, управлінець, управлінська діяльність, влада, якості, ознаки, принципи, норми
\end{abstract}

The article is devoted to one of the fundamental works of Max Weber, which is most consistent with management science as a separate field of scientific knowledge. This is a study in the field of politics, power and governance, which is quite clearly and argumentatively presented by M. Weber in his work "Call to Politics". In it, the scientist makes a detailed analysis of the role and importance of politics as a profession; who can be called to politics; what should be a politician, manager; what are the rules and principles of policy; what qualities of managerial culture should be possessed by politicians, managers, as well as - whether these qualities are possible in political and managerial activities.

Today, politics is very closely linked to such an institution of the state as power and governance. It is a profession of management, as the management of state and public affairs is taken over mainly by political parties, associations and individual politicians-leaders. History is good or bad, but now it is a reality, an objective fact. Based on this, the development of classics on politics as a profession, which should be engaged in vocational, professionally trained people, becomes relevant.

Unfortunately, modern Ukrainian politics does not quite meet the criteria that M. Weber writes about. Hence the problem of bringing to them scientific and practical developments, ideas and theories of the classics of managerial thought, which is certainly $M$. Weber. In this publication, the author will try to present in an accessible form the views of the scientist on politics and politics-manager, as well as what features and qualities of management culture should have a Ukrainian politicum, which represents public administration.

This article is a continuation of the author's publication, which was published in the 16th issue in 2020 of the magazine "Public Administration in Ukraine", namely "Three pure types of legitimate domination": the managerial culture of $M$. Weber and modernity.

Key words: managerial culture, policy, manager managerial activity, power, qualities, signs, principles, norms
Постановка проблеми в загальному вигляді. Макса Вебера як науковця знають і пов'язують здебільшого із соціологічними знаннями. Це правильно, оскільки він був знавцем світових релігій, одним із засновників соціології релігії, соціології праці, соціології культури, соціології політики, історичної соціології тощо. Менше його знають як класика управлінської думки, хоча в нього є декілька фундаментальних праць, що присвячені саме проблематиці управління, політиці, економіці, владним інституціям: «Господарство і суспільство», «Три чисті типи легітимного панування»,
«Покликання до політики», «Політичні спільноти і господарство» та інші. Його науковою творчістю цікавилися раніше і досліджують нині: Р. Арон, Я. Алстед, В. Моммзен, А. Гофман, А. Мартинов, М. Масловський, Б. Миронов, П. Кутуєв, Ю. Баришніков, В. Маршев та інші.

Проте науковців, які вивчали і вивчають його спадщину саме з позицій управлінської думки, дотепер мало в Україні. Назвемо деяких із них: О. Погорілий, В. Скиба, М. Туленков, Н. Юрик, Н. Бутусова, В. Пержун та інші.

Отже, дослідження політики й управління як взаємопов'язаних соціально-політичних і дер- 
жавно-управлінських феноменів, що зробив М. Вебер у праці «Покликання до політики», важливе, оскільки він розглядає проблеми політичного поля суспільства і держави, управлінської діяльності, управлінської культури, загалом, яким має бути політик і управлінець. Ці питання мають не тільки науково-теоретичне навантаження, але й постають практичними завданнями для сучасного українського політикуму.

Аналіз публікацій за проблематикою та визначення не вирішених раніше частин загальної проблеми. Серед праць, де досліджуються окремі моменти, пов'язані з науковою роботою М. Вебера в галузі управлінської науки, назвемо такі: «Дослідження авторитарної особистості» Т. Адорно, «Сучасний соціальний конфлікт: нарис політики свободи» Р. Дарендорфа, «Демократія і тоталітаризм» Р. Арона, «До загальної теорії дії. Теоретичні засади соціальних наук» Т. Парсонса, «Ефективність людської поведінки» Н. Чубаря, «Наглядач імперії» А. Філіпова, «Організація і управління» Д. Гвішіані, «Технології політичної влади» В. Іванова і В. Патрушева, «Сучасні теорії менеджменту» М. Туленкова, «Три чисті типи легітимного панування»: управлінська думка М. Вебера і сучасність» В. Пержуна й інші.

Однак і дотепер залишаються маловивченими, особливо в управлінській думці, напрацювання М. Вебера стосовно політики як соціального інституту влади, політиків, що займаються управлінською діяльністю, які риси управлінської культури їм мають бути притаманні тощо. Такі наукові та практичні проблеми будуть вивчені в цій статті.

Мета статті. Проаналізувати основні характерні якості й ознаки управлінської культури політиків-управлінців, які визначає М. Вебер у своїй праці «Покликання до політики», а також їх використання сучасним українським політикумом.

Виклад основного матеріалу. На початку своєї праці М. Вебер порушує питання, що має володіти людиною, чим вона живе в поточний момент, щоб вирішити стати на шлях політичної й управлінської діяльності. На дане питання він відповідає коротко: це «<...> те, що дає почуття влади» [4, с. 173]. Далі вчений пише, що поступово змінюється свідомість і поведінка людей, які прийшли в політику й отримали владу, вони починають відчувати себе «<...> нервом історично важливого процесу, коли проявляється здатність людини підняти професійність політика над повсякденністю» [4, с. 173]. Але тут М. Вебер наголошує, що політикам важливо пам'ятати про ту важку ношу, що покладається на них: відповідальність за свої дії, роботу своїх підлеглих й оточення, зрештою, відповідальність за державу і суспільство. Отже, «<...> ми торкаємося сфери етичних питань, бо саме до них належить питання, якою слід бути людині, щоби їй дозволено було покласти руку на спиці колеса історії», - пише М. Вебер [4, с. 173].

Наступний ключовий момент, на який звертає увагу М. Вебер, це виокремлення трьох основних, на його думку, якостей, якими мають бути наділені політики:

- пристрасть (розуміння суті справи, як її можна успішно вирішити, відданість цій справі);

- почуття відповідальності (відповідальність має бути в політиків та управлінців завжди, вона ніби вимір їхньої практичної роботи);

- окомір діяльності (це власне управлінська культура, яка виступає орієнтиром управлінської діяльності, внутрішня готовність до результативних дій).

М. Вебер підкреслює: «Пристрасть - у розумінні спрямованості на саму суть справи (Sachlichkeit): пристрасної відданості «справі», тому богові чи демонові, який вершить цю справу» [4, с. 173]. Водночас він зауважує, що тільки однієї пристрасті політикові, який бачить її своєю професією, недостатньо для повноцінного самовираження в управлінській чи владній діяльності: «Вона не зробить вас політиком, якщо, будучи відданим «справі», ви не вважатиме відповідальність перед цією справою провідною зіркою вашої діяльності» [4, с. 174]. І, як підсумок, далі наполягає: «<..> Для цього (і то головна психологічна якість політика) потрібен окомір - здатність із внутрішньою зібраністю та спокоєм віддатися впливу реальностей, інакше кажучи, потрібна дистанція стосовно речей і людей» [4, с. 174].

Деяку увагу М. Вебер також приділяє суто психологічним якостям політика. Він говорить, що людина, яка вважає політику своєю професію, має в управлінській діяльності керуватися передусім розумом: «Політику роблять головою, а не якимись іншими частинами тіла або душі <..> Але повне приборкання душі, яке притаманне пристрасному політикові і яке відрізняє його від «стерильно збудженого» дилетанта, можливе тільки завдяки звичці до дистанції - у будь-якому розумінні цього слова. «Сила» політичної «особистості» передусім означає наявність у неї вищезгаданих якостей» [4, с. 174].

Далі М. Вебер пише про одну особливість, до того ж не позитивну як для політика й управлінця, що навіть нині вельми актуальна й болюча для нашого українського політикуму. Ця якість притаманна, на жаль, більшості полі- 
тиків і управлінців в Україні. Ідеться про «<..> цілком тривіальну, занадто людську ваду звичайнісіньке марнославство, смертельного ворога всякої самовідданості справі і всякої дистанції, у даному разі - дистанції щодо самого себе» [4, с. 174].

Тут М. Вебер наголошує, що марнославство притаманне багатьом людям різних професій, але коли ми маємо на увазі політика чи управлінця, дана проблема особливо актуалізується, оскільки для нього його праця - це прагнення влади як необхідного засобу для самовираження і самоутвердження. I в цьому немає нічого поганого, оскільки «<... « «інстинкт влади», як його прийнято називати, справді належить до нормальних якостей політика» [4, с. 175]. Але коли цей інстинкт починає працювати не на державну і суспільну справу, а тільки на благо самого політика, його родини і близького оточення, тоді відбуваються речі, що призводять до нездорового управління, зловживання владою, зрештою, дуже часто, до політичного краху самого політичного діяча та його команди. Стосовно такого стану М. Вебер зауважує: «Гріх проти святого духу його покликання починається там, де прагнення влади стає неділовим (Unsachlich), перетворюється на предмет особистого самозахоплення, замість того, щоб служити виключно «справі». Бо у сфері політики є, зрештою, два різновиди смертельних гріхів: байдужість до суті справи (Unsachlichkeit) i (що часто, але не завжди поєднане з нею) безвідповідальність» [4, с. 175]. Підсумовуючи ці небезпеки для політика, автор праці «Покликання до політики» наполягає, що найперше до них можуть призвести виключно марнославство, байдужість, егоїзм, популізм, видимість роботи, возвеличення своєї влади, безвідповідальність тощо. Справді, написано ніби сьогодні й звучить для наших сучасних українських управлінців, політиків та влади.

Що також важливо й актуально для наших українських політиків і управлінців у згаданій праці М. Вебера, що він відверто пише про етичні (відношення між етикою і політикою) і моральні норми та принципи. Учений наполягає на тому, щоб політики займалися дійовими внутрішніми справами в соціальній та економічній сферах. Стосується це тодішньої Німеччини, яка програла Першу світову війну. Вони, тобто політики, на його погляд, мають сказати: «Ми програли війну - ви її виграли. Із цим тепер усе вирішено. Давайте ж вести мову про те, які із цього варто зробити висновки відповідно до тих ділових інтересів, які були задіяні, і - що найголовніше - $з$ погляду тієї відповідальності перед майбутнім, яка лежить передусім на переможцеві. Усе інше $€$ недостойним і мститиме за себе. Нація стерпить ущемлення її інтересів, але не стерпить образи її гідності, особливо коли це роблять із попівською впертістю» [4, с. 177].

Дилема співвідношення етики і політики, чи може бути політик моральним, чи виправдовує себе підхід, що досягнення кінцевої мети виправдовує всі можливі засоби, приводить М. Вебера до констатування факту: «Неможливо носити під одним капелюхом етику переконання й етику відповідальності або ж етично декретувати, яка мета мусить освячувати які засоби (за умови, що цьому принципові взагалі робляться якісь поступки)» [4, с. 183]. Для людини, яка вирішила присвятити себе професійно політиці й управлінню, украй необхідно знати, осмислити й усвідомити такі «етичні й моральні перебіги», коли добро не завжди перемагає зло, а в політиці, у більшості, навпаки; коли настає необхідність «відмовитися» від здавалось би доброго й людяного вчинку й робити справи та реформи, непопулярні серед людей тощо.

Тепер декілька слів про етику переконання й етику відповідальності у сфері політики. М. Вебер не відкидає етику переконання, інколи вона спрацьовує, але він замислюється над питанням: «<..> чи варто діяти відповідно до етики переконання, а чи до етики відповідальності, і коли так, а коли інакше, - цього нікому приписати не можна» [4, с. 189]. Історія знала і знає приклади, коли з'являються політики переконання і говорять, що я намагався і намагаюся робити все добре, але мені не вдається, оскільки заважають; відповідальність за наслідки не може лежати на мені, а на інших, які мене оточують, моїх опонентах тощо. Чи не нагадує це наших політиків та їхні слова про «попередників»? М. Вебер на це відповідає: «<...> Скажу відверто, що спершу запитаю про міру тієї внутрішньої повноцінності, яка стоїть за цією етикою переконання; у мене складається враження, що в дев'яти випадках із десяти я маю справу із хвальками, які не відчувають реально, що вони беруть на себе, але зачаровуються романтичними ілюзіями» [4, с. 189]. Досить влучно сказано, ніби М. Вебер живе в сучасній Україні.

Але можлива й зовсім інша картина. У певний історичний момент 3'являються люди 3 етикою відповідальності за наслідки своєї політичної та державної управлінської діяльності. У їхній управлінській роботі не все може бути правильним та зразу результативним, вони можуть помилятися і шукати шляхи вирішення проблем, зрештою, ідеальних політиків та управлінців не буває. Але якщо така 
людина відверто скаже: «я інакше не можу, на цьому стою», тут є щось справді людське і зворушливе. Бо це якраз та ситуація, яка для кожного з нас, хто, звичайно, внутрішньо не вмер, повинна мати можливість колись настати. У цьому розумінні етика переконання й етика відповідальності не $€$ абсолютними протилежностями, а взаємно доповнюють одна одну, які тільки разом становлять справжню людину, яка може мати покликання до політики» $[4$, с. 189].

Як підсумок можна сказати, що М. Вебер упевнений, що «політика - це могутнє повільне буріння твердих пластів, яке здійснюють водночас із пристрастю і з холодним окоміром» [4, с. 191]. Не кожна людина здатна бути політиком, володіти владою й управляти суспільством і державою. Така людина має відчувати в собі відповідальність, окомір і пристрасть, мати внутрішню здатність керувати і владарювати, водночас намагатися робити «усе в міру», як говорив у далекому історичному минулому «батько» афінської демократії Солон. «Лише той, хто впевнений, що не похитнеться, коли світ виявиться, з його погляду, надто дурним або надто підлим для того, що він хоче йому запропонувати; лише той, хто, всупереч усьому, здатний сказати: «А все-таки!», - лише той має «професійне покликання» до політики», - переконаний М. Вебер [4, с. 191].

Тепер стосовно перспектив формування управлінської культури українських політиків та управлінців, про які висловлювався М. Вебер. Найперше необхідно позбутися популізму й безвідповідальності в управлінській роботі. Неможливо обіцяти того, що не виконаєш. Краще, як пише М. Вебер, стати відповідальним політиком, стратегічно мислити, системно підходити до вирішення назрілих соціально-економічних, соціокультурних, політичних проблем. Адже втілити в життя реальні цивілізовані реформи непросто, часто доводиться робити речі непопулярні, але якщо політик, управлінець та їхня команда на правильному шляху, рано чи пізно це принесе свої позитивні результати. Які шляхи формування такої управлінської культури? Найперше людина має зрозуміти й усвідомити, чи це твоє - політика й управління; наступне - навчання, здобуття досвіду; далі - добір у свою команду професійних управлінців, уміння слухати і прислуховуватися до порад експертів та консультантів; і останнє - це політична воля керівництва зробити реальні практичні кроки до позитивних політико-управлінських реформ в Україні. Усе це нелегко, оскільки багатьом впливовим людям реальні позитивні зміни в сучасній Україні не потрібні, вони обстоюють стару систему, коли державна бюрократична машина тільки гальмує цивілізаційний поступ. Але процеси реформ і змін - це незворотні речі, що рано чи пізно принесуть успіх у розбудові української держави. I належне місце в даних процесах належить сформованій позитивній управлінській культурі українського політикуму. Про такі управлінські реалії сьогодення пишуть українські вчені, які працюють у сфері державного управління й займаються управлінською наукою: В. Бакуменко [2], Г. Атаманчук [1], Л. Васильченко [3], О. Петроє [7], Л. Гонюкова [5], М. Пірен [8], Ю. Сурмін [9], В. Тертичка [11], С. Телешун [10], В. Пержун [6] та інші.

Висновки. Зроблений аналіз праці «Покликання до політики» М. Вебера засвідчує, що він як учений і громадсько-політичний діяч, прихильник національно-ліберальної ідеології обґрунтовує концептуальні засади аналізу політики як соціального феномену й інституту влади й управління. Науковець ніколи не заперечував вагомого впливу економічних чинників на політику, але й ніколи не був прихильником тези, що політика $є$ «надбудовою» над економічним фундаментом, а завжди розглядав ї̈ як окрему сферу соціально-політичних відносин у галузі влади й управління. Найбільше уваги М. Вебер приділяє мотиваціям, якими керуються суб'єкти політичних відносин і це ми вважаємо доцільним, оскільки політики-професіонали є тими людьми, від яких багато в чому залежить соціально-політична, економічна та соціокультурна життєдіяльність суспільства і держави.

Перспективою подальших досліджень $€$ вивчення розробок М. Вебера стосовно соціально-психологічних чинників, що впливають на політику, владу й управління. Потребує також більш поглибленого вивчення його теорія соціальної дії у сфері політики й державного управління.

\section{ЛІТЕРАТУРА:}

1. Атаманчук Г. Про особливості профресіоналізму в управлінні. Право та управління XXI cmoліття. 2012. № 2. С. 56-61.

2. Бакуменко В. Формування державно-управлінських рішень: проблеми теорії, методології, практики : монограсрія. Київ : УАДУ, 2002. 328 с.

3. Васильченко Л. Управлінська культура і компетентність керівника. Харків : Основа, 2007. 176 с.

4. Вебер М. Соціологія. Загальноісторичні аналізи. Політика. Пер. 3 нім. О. Погорілого. Київ : Основи, 1998. 532 с.

5. Гонюкова Л. Політичні партії в державному управлінні : фуункціональний аспект. Збірник наукових праць Національної академії державного управління при Президентові України. 2010. № 4. С. 191-198. 
6. Пержун В. «Три чисті типи легітимного панування»: управлінська думка М. Вебера і сучасність. Публічне управління $i$ адміністрування в Україні : науковий журнал Причорноморського науково-дослідного інституту економіки та інновацій. Херсон : Видавничий дім «Гельветика», 2020. Вип. 16. С. 24-28.

7. Петроє О. Еволюція моделі державного управління: від класичних демократій до врядування майбутнього. Збірник наукових праць Національної академії державного управління при Президентові України. 2019. Вип 2. С. 92-106.

8. Пірен М. Профресійна відповідність управлінської культури керівників владних інститутів - об'єктивна потреба суспільних змін в Україні. Збірник наукових праць Національної академії державного управління при Президентові України. 2018. № 4. С. 150-157.

9. Сурмін Ю. Необхідність концептуальних змін професійного навчання державних службовців в Україні. Збірник наукових праць Національної академії державного управління при Президентові України. 2005. № 4. С. 84-92.

10. Телешун С. Управління людьми в нестабільному інституційному середовищі: світові та українські реалії. Збірник наукових праць Національної академії державного управління при Президентові України. 2019. № 1. C. 60-66.

11. Тертичка В. Системний підхід як підґрунтя аналізу державної політики. Збірник наукових праць Національної академії державного управління при Президентові України. 2005. № 1. С. 76-86. 